\title{
Tackling offensive behaviour in Scottish football: A how (not) to guide to developing criminal justice policy?
}

Criminology \& Criminal Justice 2022, Vol. 22(I) 24-42 (C) The Author(s) 2020

(c) (i)

Article reuse guidelines: sagepub.com/journals-permissions DOI: $10.1177 / 1748895820912313$ journals.sagepub.com/home/crj

@SAGE

\section{Maureen McBride $1 D$ \\ University of Glasgow, UK}

\begin{abstract}
Since 20 I I, the issue of 'sectarianism' has dominated the Scottish political agenda as well as media and public discourse. The most high-profile aspect of the Scottish Government's response to the problem was undoubtedly the Offensive Behaviour at Football (Scotland) Act 20I2. This article is based on analysis of official documentation, speeches and media coverage relating to sectarianism and the Offensive Behaviour at Football and Threatening Communications Act since 20II. By tracing the Act's journey from its introduction to its repeal in 2018, it challenges notions of a policymaking process built on consensus. It also casts doubt upon the Scottish Government's claims of a socially progressive approach to criminal justice, as the behaviours of working-class youth around football have been increasingly problematised, criminalised and regulated. I argue that the Act highlights the need for an ongoing critique of the direction of criminal justice in Scotland and demonstrates the consequences of knee-jerk responses to complex social problems, which has relevance beyond the Scottish context.
\end{abstract}

\section{Keywords}

Football, inequalities, policing, policymaking, sectarianism

\section{Introduction}

In recent years, the issue of 'sectarianism'" in Scotland has attracted significant political and media attention. Concerns about the volume and impact of 'sectarian' marches and parades led to a review and a set of recommendations for governing bodies which was published in 2005, and the Scottish Government held summits on sectarianism in 2005

\section{Corresponding author:}

Maureen McBride, School of Education, University of Glasgow, Room 203, Adam Smith Building, 40 Bute Gardens, Glasgow GI2 8RT, UK.

Email: Maureen.mcbride@glasgow.ac.uk 
and 2006. The Scottish media's long-standing interest in the relationship between football and sectarianism has also drawn attention to the costs and pressures on health and policing services as a result of anti-social behaviour and violence surrounding 'Old Firm'2 matches (see BBC News, 2011c). Against this backdrop of existing concerns, the early months of 2011 saw a series of high-profile attacks with apparent racist and/or sectarian motives on people with connections to Catholicism, Ireland or Celtic Football Club (or a combination of the three), including death threats and the mailing of bullets and viable parcel bombs (McBride, 2018). A football match between Celtic and Rangers on 2 March 2011 accelerated what Lavalette and Mooney (2013) describe as a 'panic reaction' regarding alleged sectarianism in Scotland (p. 24), within and outwith football. Media, political and public discourse constructed supporters of Celtic and Rangers in moralistic terms, as a 'problem population' intent on expressing 'unacceptable identities' (McBride, 2011) which were, in the words of the SNP's (Scottish National Party) Community Safety Minister Roseanna Cunningham, not in keeping with visions of a 'modern Scotland' (BBC News, 2011a).

The anti-sectarianism agenda that emerged from these events involved two broad policy and legislative strands. Since 2011, the Scottish Government committed $£ 13.5$ million funding to educational initiatives and community-based programmes to 'understand the specific causes and impact of sectarianism in Scottish society' (SNP, 2015) and established an Advisory Group on Tackling Sectarianism with a remit to explore the nature and extent of the problem. The other strand - the most contested aspect of the anti-sectarianism agenda and the focus of this article - was the creation of the Offensive Behaviour at Football and Threatening Communications (Scotland) Act (2012) (hereafter the OBTC Act). ${ }^{3}$ The decision to introduce legislation solely targeting football supporters was contentious, given that the controversy around the above-mentioned match related to on-field clashes between players and managers, as opposed to increased levels of disorder among fans. Moreover, the high-profile incidents appeared to be characterised by anti-Irish and anti-Catholic bigotry as much as by antipathy towards Celtic Football Club. The OBTC Act deeply divided opinion in Scottish football, Scottish politics and Scottish society more broadly. It was the first piece of legislation to pass without any cross-party support and was later labelled by Labour MSP (Member of Scottish Parliament) James Kelly as 'the worst piece of legislation in the history of the Scottish Parliament' (Bews, 2018). The Scottish Parliament repealed the Act in 2018 after a sustained period of activism from supporters' groups and opposition parties uniting to defeat the minority Government. However, the Scottish Government remained steadfast in its defence of the legislation throughout years of criticism.

This article argues that the OBTC Act is a powerful case study of how the framing of a problem requiring policy attention and the resultant policymaking process - both of which are inherently political - can determine how 'punitive' or 'progressive' a criminal justice response will be. Through analysis of official documentation, speeches and media coverage, this article makes two principal, related arguments. First, the OBTC Act challenges the Scottish Government's narratives of a cooperative style of policymaking (Cairney et al., 2016). The Act was introduced and implemented in a highly top-down manner, and critics accused the Government of ignoring legitimate criticism and pursuing a largely tokenistic consultation. This is particularly pertinent given the complex, 
contested nature of sectarianism. As legislative responses are shaped by the ways in which a problem is understood, one might have expected a consultative approach to try to bring together a range of competing perspectives. Second, analysing the OBTC Act offers an important insight into the direction of criminal justice policy in Scotland. Far from the social welfarist approach which is supposed to characterise Scottish criminal justice policy, and indeed is reflected in other criminal justice policies, the punitive nature of the Act arguably entrenched social inequalities. Supporters - who are predominately young men, often from working-class backgrounds - were constructed as a problem population in need of increased policing and legislative control, while equivalent behaviours in other contexts were not subject to the same attention. This undermines claims of the current Scottish Government that they have been more progressive than their predecessors in Scotland and, in comparison, the UK Government.

\section{A 'Scottish approach' to criminal justice policymaking?}

The 'Scottish approach' to policymaking (Cairney et al., 2016) refers to the Scottish Government's 'reputation for pursuing a consultative and cooperative style when it makes and implements policy in devolved areas' (p. 333). This progressive policymaking style is underpinned by a commitment to social justice driven by apparently 'Scottish values'. Such narratives frequently juxtapose the 'Scottish approach' against the 'worst excesses of 'neoliberal' UK government and governance' (Cairney et al., 2016: 346). In the criminal justice sphere, Scotland has historically been understood to have pursued a less punitive and more welfare-based set of policies compared to the rest of the United Kingdom. Mooney et al. (2015: 210) argue that social welfarist values were a strong driver in the pre-Devolution approach to youth justice, with more emphasis on rehabilitation than punishment. Scotland was considered to have a more progressive approach to prison policies (McAra, 1999), and policing in Scotland was often constructed as less controversial than in England even if this 'benign reputation' is unmerited (Murray and Harkin, 2017). Keating et al. (2003) refer to Scotland's social democratic tradition and a 'more consultative and consensual policy style, which makes radical policy change more difficult in the short term' (p. 18). However, it is generally accepted that the notion of policy divergence is in practice highly uneven. For example, Mooney et al. (2015) highlight the high prison population - which in 2018 was 143 per 100,000 of the national population, one of the highest imprisonment rates in Europe (Howard League Scotland, 2018) - as evidence of the system's more punitive elements.

The early years of devolution saw pressure on Scottish Labour to follow 'tough on crime' ${ }^{4}$ New Labour policies, which posed further challenges to notions of 'Scottish distinctiveness'. The Labour-Liberal Democrat Coalition Government in Scotland initially helped restrain a 'punitive turn', 5 as Keating et al. (2003) note that the presence of a Liberal Democrat at the Justice Department meant there was 'less emphasis on hardline law and order policies' in Scotland (p. 18). However, the 2003 election campaign saw a breakdown in this arrangement, and 'Labour's insistence on tougher law and order policies was an issue in the subsequent coalition negotiations in which Labour insisted on new measures and took the Justice portfolio into its own hands' (Keating et al., 2003: 18). Mooney and Scott (2012) state that youth justice policy since devolution has become 
increasingly punitive, representing the 'erosion of the more welfarist approach to youth justice policy making that had characterised the period up to the late 20th century' (pp. 8-9). Law and Mooney (2012: 5) highlight the increasingly punitive approach within the Scottish criminal justice system, particularly the emphasis on anti-social behaviour and young people in public spaces which culminated in the Antisocial Behaviour etc. (Scotland) Act 2004. ${ }^{6}$ The anti-social behaviour framework developed in Scotland was substantially different from the model in England and Wales, with more focus on prevention and fewer disciplinary elements. The 'ASB family projects' established in Scotland had less emphasis on threatening sanctions, which some scholars attribute to the history of a more welfarist approach (Nixon et al., 2010). Nonetheless, there remained clear punitive elements, and the fact that in the early post-devolutionary period, there was significant convergence with the rest of the United Kingdom resulted in claims of Scotland's 'detartanisation'7 (McAra, 2008).

For some, the 2007 election which saw the SNP establish a minority Government signalled the 'retartanisation' (McNeill, 2011) of Scottish justice policy. Political rhetoric from the new First Minister and other leading nationalist politicians was less focused on punitive measures and seemed to indicate a shift away from responding to social problems with punitive legislation. Kenny MacAskill's appointment as Justice Secretary was considered to boost the ability of this new minority Government to pursue more progressive policies (MacLennan, 2016). Cairney (2011) notes that MacAskill was 'linked strongly to its agenda on sentencing reform and the eventual abolition of prison sentences below six months in favour of community service' (pp. 196-197). Furthermore, the new minority Government 'downplayed ASBOs and concerns about persistent young offenders' (Croall, 2012: 187), thus differentiating Scotland from the rest of the United Kingdom. The extent to which positive political rhetoric was translated into reform on the ground during the SNP minority government period (2007-2011) was limited: 'all the major parties had fairly punitive agendas' (Cairney 2011: 197). However, with the SNP's success in the 2011 Scottish Parliament elections, after which it was able to establish a majority Government, 'the scene was set for more radical and far-reaching reforms than had been feasible prior to the political shift' (Armstrong and Munro, 2017: 139).

Importantly for the purposes of this article, there was a convincing sense that rushing to legislate to solve social problems would not be the norm going forward. So, we might expect divergence to be more evident in how criminal justice policy develops in Scotland. The framing of the new Scottish Parliament was a desire to 'do politics differently' (Keating et al., 2003). And there were signs that as the SNP gained power, lessons had been learned from Labour's 'tough on crime' approach. Respondents in Mooney et al.'s (2015) study on criminal justice policymaking between 1999 and 2007 spoke of a shift in approach: 'Gone was the constant rush to respond and talk up criminal justice in crisis terms' (p. 217). Carnochan (2017) notes that 'the new Government seemed to recognise the necessity to focus whole systems collaboratively on issues identified locally, delivering solutions locally and involving local communities in the process' (p. 151).

This article explores the OBTC Act as a case study of policy development (and indeed policy reversal) in Scotland. It follows the approach by Mooney et al. (2015) that 'sees the development of criminal justice policy in Scotland as no mere technical process but as one that recognizes how politics intervenes at every step of the policy-making process' 
(p. 207). It is argued herein that the OBTC Act represented a punitive framing of criminal justice policy which challenges Scottish Government narratives of a progressive approach. However, the OBTC Act must also be placed in the broader context of how sectarianism in Scotland has been framed historically, and how the complex and contested nature of the issue posed problems for the SNP Government's attempt to develop a consensus around their approach.

\section{The politics of tackling sectarianism}

Although space does not permit an in-depth analysis of the nature and extent of sectarianism in contemporary Scotland, a summary of key academic debates is important for our understanding of a piece of legislation which was ostensibly designed to tackle the issue. One influential school of thought contends that the extent of sectarianism in Scotland has always been subject to exaggeration and conjecture (Bruce et al., 2004). Even when the impact of sectarianism on social relations historically is acknowledged, demographic indicators such as rates of intermarriage and improved educational and employment outcomes for Catholics are cited to demonstrate the decline of socioeconomic inequalities and to deem sectarianism a 'thing of the past' (Bruce and Glendinning, 2017; Bruce et al., 2004; Rosie, 2015). In this view, sectarianism is described as a Protestant-Catholic divide which a 'mindless minority' refuse to leave behind despite Scotland's increasingly secular nature (Bruce and Glendinning, 2017; Bruce et al., 2004; Rosie, 2015). This argument is largely supported by the historian Tom Devine, whose work on Irish migration to Scotland previously emphasised the inequalities faced by Irish Catholics (Devine, 2008), but who now contends that since the decline of structural discrimination, sectarianism is 'on its deathbed' (Devine, 2018). The characterisation of sectarianism as 'inter-communal tension and conflict between ideologically opposed groups' (May, 2015: 1), or as discrimination towards others 'on the basis of their perceived denominational background' (Scottish Government, 2015: 24), and the use of language such as 'differences' and 'animosity' (Rosie, 2015), posit the problem as one of tension between two communities.

Some scholars criticise the above position for paying insufficient attention to power relations or the legacy of historical inequalities and present alternative explanations which emphasise the anti-Catholic and anti-Irish nature of most of what is understood to be 'sectarianism', and argue that debates should acknowledge the impact of historical patterns of inequality and oppression in Scotland and Ireland (Bradley, 2006; Kelly, 2010; McBride, 2018). This work emphasises the economic, social and cultural marginalisation of the Irish Catholic minority in Scotland, who occupied a lower socioeconomic position compared to the Protestant majority until towards the late 20th century (Bradley, 2006; Devine, 2008; McBride, 2018). It is notable that this perspective has previously had to contend with claims of partisanship and an over-reliance on 'anecdotal' evidence (see Bruce et al., 2004; Walker, 2001). For example, Walker (2001) contrasts the work of Bruce et al. (2004) to the 'other scholars of the Catholic community, all of whom, perhaps significantly, are drawn from its ranks' and whose work is characterised as having a 'pronounced sense of defensiveness and of scepticism' (p. 43). However, academics increasingly point to the relevance of historically unequal power relations. For Malloch 
and Goodall (2013), popular understandings of sectarianism detracts from 'an imbalance of power between the larger group of mostly Scottish-originating Protestants and the smaller group of Scottish and Irish Catholics' (p. 176), and Flint and Kelly (2013: 6) argue that more attention should be paid to power dynamics and key contextual factors such as Rangers' history of not knowingly signing Catholic players while Celtic did not have an equivalent signing policy. ${ }^{8}$

Some academics critique the concept of sectarianism and suggest that popular understandings of sectarianism mean that the expression of Irish Catholic or Ulster-British identities are frequently deemed to be bigoted in themselves. For example, Kelly (2010) argues that expressions of Irish Republicanism are frequently and incorrectly constructed as sectarian: 'having a stated position on Irish politics . . . is sufficient condition to be labelled sectarian' (pp. 2-3), resulting in what he describes as 'an apolitical and culturally naïve version of sectarianism'. Flint and Kelly (2013) state that the term 'bigotry' might be preferred to 'sectarianism' and argue that 'the actual problem is not one of Irish/Ulster identification or expression but rather one of religious bigotry and ethnic intolerance (racism)' (p. 4). The authors argue that analysis should focus less on expressions of identities and instead on actions of intolerance or bigotry towards different ethnic, religious and national groups.

Polarisation in academic debates - particularly on controversial issues such as sectarianism - is not unusual. However, in this case study of the development of the OBTC Act, it is important to explore the question of which voices and perspectives have influence in the policy process. An illuminating example is the inclusion of Professor Duncan Morrow and Dr Michael Rosie on the Advisory Group on Tackling Sectarianism from 2012 to 2015. As well as chairing the Advisory Group, Morrow was tasked with producing a report in 2017 reviewing the group's recommendations. In 2016, he was invited to chair an Independent Advisory Group on Hate Crime, Prejudice and Community Cohesion. In 2018, Morrow was tasked with overseeing an independent working group to come up with a legal definition of sectarianism (the Scottish Government Working Group on Defining Sectarianism in Scots Law), which Michael Rosie was subsequently appointed to. Rosie also served as an Independent Advisor to the Scottish Government on the issues of marches and parades from 2015 to 2016.

Commenting on a perceived imbalance in terms of which academics have policy influence, Dr Joseph Bradley suggests that there is a favoured narrative which is in line with the Scottish Government's position:

We'll get nowhere in terms of learning and understanding if it's the same bodies, same academics, that get yet more money to say the same things: the things that actually just simply re-cycle the established 'wisdoms' about so called 'sectarianism'. (Harkins, 2018)

The questions of whose work has influence, and what kinds of evidence carry weight, are pertinent. Although all academics have the opportunity to influence policy (e.g. in consultations such as that carried out for the OBTC Bill), to be included in advisory groups and to be commissioned to author reports for the Scottish Government indicates a different level of participation in policy development. Morrow and Rosie, and the particular perspectives underpinning their academic work, had visibly more influence than those with more critical perspectives. 
The introduction of the OBTC Act must be seen in the broader context of the highly charged debates on the nature and extent of sectarianism outlined in this section. After years of little attention from the state (Law, 2016), the sudden rush in early 2011 to tackle the problem through legislation was likely to have political ramifications. Previous experience in the football sphere through the implementation of Football Banning Orders (FBOs) suggested that 'the particularities of the Scottish context' were not sufficiently taken into account in the development of the legislation which had previously been used elsewhere in the United Kingdom to tackle hooliganism as opposed to sectarianism (Hamilton-Smith and McArdle, 2013: 141). Existing literature on the Act focuses on the neglect of gender in debates on the legislation (Malloch and Goodall, 2013) and on the politicisation of sectarianism and anti-sectarianism (Crawford, 2013). May (2015) analyses the relationship between the Act and national identities, and Waiton (2018) argues that the legislation was constructed by political elites in the context of growing concerns about 'offensive' language. For Crawford (2013), the introduction of the Act was a sign that 'the SNP government succeeded in winning the war over the legitimate right to define the problem of sectarianism, as well as the solution' (p. 10). However, given the recent repeal of the legislation, it is a timely opportunity to trace the Act through the policy process, and to draw out the ways in which it came to represent a both a punitive framing of criminal justice policy and a challenge to the idea of consensual policymaking in Scotland.

\section{Introducing the OBTC Act}

The OBTC Bill was introduced to Parliament just 1 month after the SNP won an overall majority in the May 2011 Scottish Parliament elections. While most of the legislation passed in the early years of the first SNP-led Government (2007-2011) received cross-party support, suggestive of efforts to build consensus across the political spectrum, in the case of this legislation, the SNP exercised its new majority. Opposition parties argued that while they concurred with the objective to tackle sectarianism, they opposed the style of policymaking that the Scottish Government had chosen, particularly the fact that efforts were initially made to pass the Bill under emergency legislation processes so that it could be in place in time for the start of the new football season in July 2011. The Policy Memorandum accompanying the Bill acknowledged that fast-tracking the legislation would limit the time for scrutiny; however, the Government believed that 'wider consultation would outweigh the risks of further damage to Scottish football and our society if we do not take immediate action to address the issues arising during the 2010/11 season' (OBTC (Scotland) Bill, 2011: 11).

Extracts from a parliamentary debate in June 2011 (Scottish Parliament Justice Committee, 2011c) illustrate how political opponents seemed to be challenging the Scottish Government to live up to their rhetoric of a consensus-building approach and to avoid rushing the legislative process:

We cannot tackle sectarianism from the top down. We need a joined-up approach that involves people from different communities throughout Scotland. (Alison McInnes, Liberal Democrats) 
In an oral presentation on the bill's provisions at the stakeholder meeting on 17 June, the civil servant tasked with advising on the policy of the Bill stated that civil servants had been instructed only some three weeks ago to produce a Bill on the issue, whereas they would normally expect the production of a Bill to be the outcome of a process of research and consultation extending over 18 months. (Helen Eadie, Labour)

First Minister Alex Salmond then announced a delay of 6 months to allow a wider consultation process to take place, stating, 'We have a majority in this chamber, but we need consensus' (BBC News, 2011b).

During the consultation process, concerns were raised by supporters' groups, most notably through the formation of Fans Against Criminalisation, a campaign group which embarked on a sustained period of resistance. Religious organisations, academics, charities, the Law Society, the Human Rights Commission and the Scottish Justices Association also expressed concerns (McBride, 2017). Critics emphasised that there was existing legislation covering the issues that the OBTC legislation apparently was created to tackle (see McBride, 2017 for summary). Several submissions to the consultation considered the Bill to be 'discriminatory' towards football supporters. It was noted that most religiously aggravated crimes took place outside of a football context (Scottish Parliament Justice Committee, 2011a: 6-7), yet the Scottish Government was unable to justify why football supporters would require control through additional law when similar behaviours in other contexts would not be subject to legislative control. The Scottish Parliament Justice Committee's (2011a) report also noted witnesses' concerns, including from equalities groups, 'that the Bill should not bring large numbers of young people into the criminal justice system' (p. 1).

However, the extension to the policymaking process and the consultation did not appease critics. Labour MSP James Kelly, a member of the Scottish Parliament Justice Committee (2011a), commented,

It seems to me that, when the Scottish Government paused back in June, which was welcomed by all, the process was frozen. It also seems to me that the Scottish Government has not interacted with the process, has not listened to the concerns that have come through in the evidence and has, therefore, adopted a take-it-or-leave-it approach on the bill. (p. 478)

Analysis of reports suggests that it was only through having a majority (five of nine) of MSPs on the Justice Committee that the SNP could claim committee support for the legislation. When the Bill eventually passed in December 2011, opposition parties issued a statement accusing the SNP of 'railroading' the Bill through parliament: 'The SNP has used its majority to force through [a] bad law that risks doing more harm than good. It sets a worrying precedent for this Parliament' (BBC News, 2011b). Despite commitment to 'high levels of consultation' in policymaking, the Scottish Government used its parliamentary majority to impose the policy in a highly top-down manner. It is, therefore, important to unpick the SNP Government's motivations for pressing ahead with the legislation in the face of widespread critique and political opposition.

In a previous study on elite perspectives on the OBTC Act (McBride, 2014), interviewees suggested that passing the legislation was a way to demonstrate political strength. They emphasised that the Scottish Government 'had to be seen to be doing 
something' in response to perceptions of increased 'sectarian' behaviour and disorder in football. Analysis of media reporting of sectarianism during the Bill's passage through the Scottish Parliament reveals a consistent narrative which constructed football supporters as 'risky' and in need of harsher social control measures (McBride, 2011). 'Official' sources, mainly from the Scottish Government or the police, were given most exposure. That is not to deny that there were legitimate concerns around, for example, marches and parades, as well as anti-social behaviour around particular football matches which had an impact on policing and health services (BBC News, 2011c). However, political discourse drew heavily from these concerns, which were often conflated and sensationalised, and the OBTC Act was presented as a coherent response to these problems.

Policy development was supposed to be based on consensus and to represent a shift away from centralisation. Yet the only consensus appeared to be between the police and an increasingly centralised Scottish Government. Significantly, the legislation would be implemented by a newly centralised police force, with the creation of Police Scotland in 2013. The Act was accompanied by a range of increased police powers and resources, including the establishment and funding of the Football Coordination Unit for Scotland (FoCUS). ${ }^{9}$ The 'politics of policymaking' was evident in how sectarianism was invoked to build a case for certain policy decisions. The Scottish Government's desire to demonstrate its competence in the criminal justice system, Police Scotland's requirement to protect resources in the context of public service cuts and heightened media interest on the relationship between football, sectarianism and violence coalesced to create the conditions for the legislation to be pushed through. As there was limited time for scrutiny and consultation, the agendas of such powerful actors were relatively unchallenged.

As well as a desire to prove its managerial competence in the criminal justice system, the Scottish Government arguably sought to position itself as more progressive than the UK Government on key moral and social issues. Judgements about which identities and behaviours were in keeping with a 'modern Scotland' came to shape policymaking: 'This Bill is a crucial first step in pursuing our vision for a better Scotland' (OBTC (Scotland) Bill, 2011: 3). May (2015) argues that the Act 'serves a political purpose in that it appears to demonstrate that the Scottish Government is committed to tackling inter-communal tension in a way that successive Westminster parliaments have not' (p. 7). Of course, politics did not only shape the Scottish Government's behaviour at this stage of the policymaking process, there was also political capital to be had from opposing a controversial piece of legislation, thus undermining the SNP as the governing party. Policy positions were undoubtedly influenced by debates on the constitutional question of Scottish independence - and who was better placed to represent Scotland's interests which increasingly divided the mainstream political parties in Scotland in these years.

\section{Responding to the 'problem' of sectarianism in football}

As Prior (2009) notes in relation to anti-social behaviour, defining a problem is a key aspect of responding to it, and it is notable that although political and media rhetoric has consistently framed the Act as an anti-sectarianism measure, the word sectarianism is absent from the text of the legislation. Indeed, the highly contested nature of sectarianism has meant that it 'has not been used in any criminal legislation in the UK' 
(Hamilton-Smith et al., 2015: 16). In the OBTC Act, the word 'offensive' is used to denote supposedly 'sectarian' or other 'anti-social' behaviours. The Act created an offence of engaging in behaviour 'in relation to a regulated football match' which 'is likely to incite public disorder' and which is hateful, threatening or 'other behaviour that a reasonable person would be likely to consider offensive'. Crucially, an offended party or a person likely to be incited to public disorder does not have to be present for the law to be enforced, a point later defended by former Justice Secretary Kenny MacAskill (2016): 'The absence of good people to be offended doesn't make something inoffensive if it patently is offensive'.

For critics, the 'reasonable person' test veers into dangerous legal territory in relation to who counts as a 'reasonable person' and the subjective nature of offensiveness. ${ }^{10}$ The 'methods of abuse' covered by the legislation give some indication of the behaviours being targeted. These are broken down into the following categories: 'Banner/flag'; 'Gesture'; 'Speech'; 'Singing'; and 'Generally offensive'. Importantly, connotations of 'offensive' behaviour arguably reinforce individualistic understandings of sectarianism in which increased regulation of football supporters is considered to be the solution. Concerns around this had been raised during the OBTC Bill's consultation process, including from those academics with critical perspectives on the issue of sectarianism and the OBTC Bill, as evidenced in the Justice Committee report (Scottish Parliament Justice Committee, 2011c). Professor Graham Walker noted that there was a significant risk of "challenging the validity of people's identity and of the expression of that identity in Scotland'. Professor Devine emphasised that there was sufficient existing legislation to tackle sectarianism, a point supported in submissions by two legal academics Dr David McArdle and Dr Sarah Christie (Scottish Parliament Justice Committee, 2011c). Dr John Kelly expressed concerns about the 'catch-all' nature of the 'reasonable person' measure (Scottish Parliament Justice Committee, 2011c), and Dr Stuart Waiton argued that working-class football supporters would be subject to criminalisation for behaviours that would be legally acceptable in other contexts, and so would no longer enjoy equal treatment under the law (Scottish Parliament Justice Committee, 2011c: 25).

The fact that these concerns were not addressed raises the question of what evidence carries weight in the policymaking process and had significant implications for the final version of the legislation. Supreme Court Judge Lord Brodie commented that the Scottish Parliament had created 'a criminal offence with an extremely long reach'. ${ }^{11}$ The extent to which this is perceived as a good or a bad thing is at the heart of debates: unnecessary criminalisation of football supporters or a necessarily tough response to a social problem?

Charges under the Act came quickly after it was brought into law on 1 March 2012. Although space does not permit an in-depth account of the Act in practice, there are some examples which illustrate the illiberal nature of the legislation. An evaluation into the implementation of the Act highlighted the fact that representatives of Police Scotland described fans as 'risk groups':

This categorisation of young supporters and 'singing sections' as risk groups, whilst potentially appropriate on occasions, also seemed commonplace and potentially problematic, in particular when sections of supporters, who whilst maybe having the potential to be offensive, were 
clearly not associated with more violent disorder, came to draw on the scarce police assets and resources normally reserved for violent risk groups. (Hamilton-Smith et al., 2015: 56)

Decisions about which songs, chants or slogans were sufficiently 'offensive' to merit a criminal justice system response was reliant 'on the subjective judgement of a police officer' (Law, 2016: 102), giving the police significant power to make moral judgements regarding the behaviour of football supporters.

Participants in previous research (McBride, 2018) described police as being more 'heavy handed' after the Act was introduced, with policing methods increasingly shifting towards surveillance tactics and the regulation of behaviour and speech. Being filmed going into games and within the stadium - something that was seemingly rare before the legislation - was raised as a key concern, and the use of cameras was overwhelmingly targeted at specific areas of the stadiums or groups of young workingclass male supporters (Hamilton-Smith et al., 2015). This risk-orientated policing approach towards groups of supporters deemed to have the potential to become involved in violent conduct naturally created division and mistrust between fans and police (McBride, 2018). There were accusations of police harassment and some 'flashpoints', including the 'kettling' of a group of Celtic supporters during a protest (Braiden, 2013). Concerns about the unnecessary criminalisation of young people with no previous criminal records appeared to have weight.

Throughout its existence, opponents of the Act consistently campaigned to have the legislation repealed. Fans Against Criminalisation (FAC, n.d.) was founded in 2011 on the basis of challenging the Act which they considered to be discriminatory towards football supporters: 'it is both discriminatory and dangerous to create a law which creates an offence for one group within a society, when the same actions or behaviours would not result in a criminal charge for others'. FAC developed petitions and organised protests, including a rally which attracted 3000 football fans in 2013 (BBC News, 2013). The group made particular use of social media to draw attention to raise awareness of the perceived injustices of the Act. They also met with opposition MSPs as well as members of the Scottish Government, and appeared at Holyrood Committees. Although fans groups' concerns seemed to be largely marginalised in the initial stages of developing and implementing the Bill, they became more active stakeholders as criticism intensified.

\section{From intensifying criticism to repeal}

Having committed to reviewing the legislation when it was passed in 2011, the Scottish Government commissioned an external evaluation of Section 1 of the Act, to be carried out by an independent research team drawn from the University of Stirling, the University of Glasgow and ScotCen Research. ${ }^{12}$ The research, undertaken between 2013 and 2015 involved a multi-method approach and consulted with a wide range of stakeholders, including football supporters, criminal justice system personnel and representatives from football clubs. The evaluation's findings were relatively balanced and included critical voices who expressed concerns about the Act's implementation as well as the principles underpinning the legislation. 
What is illuminating for the purposes of this article is the Scottish Government's handling of the evaluation. On the day of its publication on 12 June 2015, the Minister for Community Safety Paul Wheelhouse announced that the Government was responding directly to concerns about supporters with no previous criminal records being caught up in the criminal justice system by funding a 'Diversion from Prosecution' programme. $\mathrm{He}$ later suggested that this response 'chimes with concerns that have been raised by football clubs and other groups including Fans Against Criminalisation' (Scottish Parliament, 2015). Opposition politicians accused the minister of being disingenuous, and Labour MSP Michael McMahon challenged him to withdraw his remarks, stating that 'Fans Against Criminalisation see no succour in those who should not be facing prosecution in the first place being diverted away from any prosecution'.

The presentation of the evaluation's findings was notable. The ministerial statement announced that the Scottish Government had commissioned YouGov to carry out an independent poll, separate to the evaluation, yet the layout of the statement's headline which was then reproduced in media coverage - conflated the two pieces of evidence. The use of the poll also raises methodological concerns. For instance, the wording of the question which apparently saw $80 \%$ of Scots 'directly support' the OBTC Act - a key statistic cited in the ministerial statement and media coverage - was as follows:

The Offensive Behaviour at Football and Threatening Communications Act aims to tackle sectarian or offensive chanting and threatening behaviour related to football which is likely to cause public disorder. To what extent do you support or oppose this law?

To disagree with this 'leading' question would infer that one supports sectarianism and threatening behaviour. This selective and distorted use of evidence obscured much of the qualitative research conducted with supporters of various clubs over the 2 years, as well as a more rigorous survey of fans carried out by ScotCen as part of the evaluation. ${ }^{13}$ Cairney (2017) draws attention to the epistemological and methodological tensions in what constitutes 'good evidence' in policymaking, stating that there are 'political choices about which forms of evidence to prioritise and how to use evidence to inform practice' (pp. 500-501). The last-minute commissioning of the YouGov poll appears to have been motivated by a need to demonstrate that the Act was working and to offset criticism.

Debates about the Act's legitimacy culminated in the launch of the Repeal Bill in June 2017 by Labour MSP James Kelly. All four of Holyrood's opposition parties had pledged to scrap the Act in their 2016 Scottish Parliament election manifestos, and the loss of the SNP's majority paved the way for repeal. There was undoubtedly political capital to be gained by undermining the SNP and winning favour with those sections of the Scottish population who were opposed to the Act. Given that Labour had fought the 2011 election painting the SNP as 'soft on crime', a public attack on the SNP for being too punitive was a noticeable shift.

The now minority Government remained defensive in the face of criticism and political opposition. In 2016, Minister for Community Safety Annabelle Ewing commented that repeal 'threatens to set us back as a country in our efforts to effectively combat prejudice, hate crime and sectarianism and ultimately to drive such behaviour out of Scottish society' (BBC News, 2016). Throughout the process of the Repeal Bill, the tone 
of debates around the Act - from the SNP and from opposition parties - was highly confrontational and at odds with notions of consensual policymaking. The Repeal Bill was passed in March 2018 and the law was removed from the statute book the following month. It signalled the end of the line for a piece of legislation that had caused so much controversy and raised many questions about the SNP's approach to the criminal justice system and its ability to lead a consensual policymaking process more broadly.

\section{Discussion}

This article has demonstrated that the OBTC Act reveals the inconsistencies that have beset the SNP-led Scottish Government's criminal justice agenda. The rush to legislate over sectarianism symbolised the misplaced optimism that lessons had been learned from previous knee-jerk 'tough on crime' approaches to criminal justice. The speed at which the Government was willing and able to respond to the problem - compared to other social issues - suggests that working-class football supporters were considered 'easy targets', fitting into what MacLennan (2016) termed the "neds"14 agenda' of the Scottish Government and Police Scotland (p. 78). The OBTC Act must be seen in the context of broader criminal justice policies and trends which reflect the increasingly moral intervention of the neoliberal state into people's lives. Bell (2011) argues that New Labour's approach to crime was heavily based on 'social interventions designed to remoralise the underclass': a focus on culture rather than structure and blaming the 'poor' values of individuals for society's problems (p. 166). Notions of individual responsibility and other 'good' morals are inextricably linked to elite standpoints on what values are acceptable or unacceptable in the neoliberal state (Harvey, 2007: 82). Sections of the working class are represented as 'problem communities' in media and political discourses (Johnston and Mooney, 2007), essentialising the working class as deviant and requiring regulation.

The OBTC Act came into force in the context of increasing concerns relating to policing practices in Scotland. Murray (2014) found that in 2010 'the rate of stop and search per capita in Scotland was nearly four times higher than the comparable rate per capita in England and Wales' (p. 3). A key feature of 'stop and search' is the undoubtedly classed nature of its practice, with mounting evidence that it was 'employed in abundance in areas of relative deprivation and, in particular, on younger people' (MacLennan, 2016: 78). Police Scotland was accused of trying to undermine the research findings, including identifying and utilising an academic supportive of the policy to publicly counter Murray's position (Hutcheon, 2015). There are interesting parallels here with the Scottish Government's reliance on a select few academics whose view on sectarianism is in line with the status quo, and the last-minute commissioning of the YouGov poll to offset criticism of the OBTC Act as explained in the previous section. MacLennan (2016) argues that 'attempting to shut-down all discussion about policing policy reflects an illiberal streak that is becoming increasingly commonplace in the Scottish Government's approach to justice policy' (p. 74).

However, Murray and Harkin (2017) note that in the more 'heated' environment following the centralisation of Police Scotland, the relationship between the Scottish Government, the police hierarchy and the media no longer functioned to effectively 
obstruct criticism of policing practices in the way it previously had. Following intensified scrutiny, the Scottish Government announced in 2015 that non-statutory stop and search would be abolished. Stop and search and the OBTC Act were underpinned by similar assumptions - that working-class youth required increased regulation - and debates on the legitimacy of both were taking place at the same time. Yet there was no comparable political will to accept the shortcomings of the Act, and it took the loss of the SNP's majority in Parliament for the legislation to be overturned.

Was it simply that football supporters are less likely to receive sympathetic media coverage? Football has long been subject to anti-social behaviour style regulation, and the context of 24-hour rolling media coverage has escalated the demand for quick, tough responses to alleged football-related disorder. Brick (2000) described the Football (Offences and Disorder) Bill (brought in under New Labour and applicable to England and Wales) as extending the principle of harm to include acts of speech and an increasingly 'moralistic' form of regulation. Similar processes in Scotland preceded the introduction of the Act. However, this article has demonstrated that it was specific concerns about the 'sectarian' football fan - deriving from the uncritical acceptance of the longestablished narrow understanding of sectarianism - which shaped the introduction of the OBTC Act and the extent to which it was defended against criticism. This suggests that complex and controversial social problems like sectarianism in Scotland pose challenges for contemporary analysis of criminal justice policy. Research must analyse how specific problems are framed as requiring a legislative response, and uncover whose voices are included and excluded in this process.

These findings have ramifications for attempts to 'characterise' a country's criminal justice approach, or to make cross-country comparisons of criminal justice policy, given the many contradictions that can exist within a nation-state. Cairney (2016) contends that notions of a 'Scottish style' of policymaking can distract from the reality that 'all governments face the same policymaking constraints and tend to respond in similar ways' (p. 213). Despite the SNP's previously critical stance towards New Labour's 'neoliberal' approach to criminal justice, the evidence presented in this article points to much convergence with their predecessors in the Scottish Government and the UK state. It is possible that the position of strength that the SNP unexpectedly found itself in following its unpredicted majority in the 2011 election negated the need to build consensus, in line with Lijphart's (1999) characterisation of 'majoritarian' versus 'consensus' democracies. The requirement to demonstrate competence to govern perhaps outweighed its aspiration for a progressive and consensual approach to criminal justice policymaking, as espoused when in opposition and minority government. Armstrong (2018) contends that we should be wary of binary classifications of 'high' and 'low' punishment societies, because this neglects the 'specific political, historical, cultural, social, and contingent forces of a specific context', and the case study of the OBTC Act and sectarianism adds weight to this argument.

Finally, the arguments presented in this article have relevance beyond academia. Sectarianism will continue to dominate media and political discourse, and it is important that politicians and policymakers refrain from using this issue as a means of political point-scoring. This only undermines genuine grassroots efforts to tackle the problem. Relatedly, anti-sectarianism measures - whether through legislation or via 'softer' 
policies such as education or community programmes - should be underpinned by a theoretically sound understanding of the phenomenon, its historical context and how it manifests itself in contemporary society. In Scotland and beyond, lessons can be learned from the case study of the OBTC Act as a knee-jerk response to a complex and contested social problem.

\section{Acknowledgements}

The author would like to thank Dr Niall Hamilton-Smith, Dr Colin Atkinson and Dr Gerry Mooney for their constructive feedback on earlier drafts of this paper, and the two anonymous reviewers for their helpful comments.

\section{Declaration of Conflicting Interests}

The author(s) declared no potential conflicts of interest with respect to the research, authorship and/or publication of this article.

\section{Funding}

The author(s) disclosed receipt of the following financial support for the research, authorship and/ or publication of this article: This work was supported by the author's $\mathrm{PhD}$ award from the Economic and Social Research Council under research grant ES/J500136/1.

\section{ORCID iD}

Maureen McBride (iD https://orcid.org/0000-0002-9291-2175

\section{Notes}

1. 'Sectarianism' is a contested concept (see McBride, 2018). The term is used in this article because it is routinely used in academic work, political and media discourse.

2. Commonly used phrase to describe matches involving Celtic and Rangers.

3. The article focuses on Section 1 of the Act, which covers 'offensive behaviour at football matches'.

4. The Labour Government in the United Kingdom (1997-2010) sought to show strength on law and order issues.

5. 'Punitive turn' originally coined by Garland (2001) in Changing nature of crime control.

6. The authors cite a scheme in 1998 whereby young people under the age of 15 who lived in public housing estates in Hamilton (a town in South Lanarkshire with areas of high deprivation) were given an 8 p.m. curfew for 6 months.

7. The decline of a distinctively Scottish approach.

8. This practice only ceased in 1989.

9. FoCUS was set up following the 2011 'Football Summit' and aimed to develop a consistent approach to policing football-related disorder across Scotland.

10. See Scottish Human Rights Commission 2011 submission to Report on the Offensive Behaviour at Football and Threatening Communications (Scotland) Bill at Stage 2.

11. Scotcourts website, PROCURATOR FISCAL, DINGWALL v. JOSEPH CAIRNS.

12. As a part-time Research Assistant on the evaluation, I was involved in the data collection process, and to a lesser extent in the writing up of the report. However, in this article, I employ secondary analysis of the published report. 
13. ScotCen surveyed Supporters Direct Scotland members (4130 total) in two sweeps: Aug-Sept 2013 and July-Aug 2014, whereas the YouGov poll was conducted immediately before the publication of the Evaluation with a total sample size of 1044 adults (with no indication of whether football fans).

14. Commonly understood to stand for 'non-educated delinquents', it is worth emphasising that this concern with 'problematic' working-class youth predated the SNP.

\section{References}

Armstrong S (2018) The problem of punishment in a progressive society. EuropeNow, 8 November. Available at: https://www.europenowjournal.org/2018/11/07/the-problem-of-punishment-ina-progressive-society/ (accessed 30 July 2019).

Armstrong S and Munro M (2017) Scotland the just? The SNP, crime and justice. In: Hassan G and Barrow S (eds) A Nation Changed? The SNP and Scotland Ten Years on. Edinburgh: Luath Press, pp. 136-141.

BBC News (2011a) Alex Salmond announces sectarianism bill delay. BBC News, 23 June. Available at: https://www.bbc.co.uk/news/uk-scotland-13883763 (accessed 31 May 2019).

BBC News (2011b) Anti-bigot laws passed by the Scottish Parliament. BBC News, 14 December. Available at: https://www.bbc.co.uk/news/uk-scotland-scotland-politics-16138683 (accessed 23 May 2019).

BBC News (2011c) Cost of policing Old Firm fixtures was almost $£ 2.4 \mathrm{~m} . B B C$ News, 22 July. Available at: https://www.bbc.co.uk/news/uk-scotland-glasgow-west-14251800 (accessed 13 November 2019).

BBC News (2013) Celtic fans hold rally against football law. BBC News, 6 April. Available at: https://www.bbc.co.uk/news/uk-scotland-glasgow-west-22041832 (accessed 21 November 2019).

BBC News (2016) Government defeated in Offensive Behaviour at Football Act vote. $B B C$ News, 2 November. Available at: https://www.bbc.co.uk/news/uk-scotland-scotland-politics-37835502 (accessed 17 April 2019).

Bell E (2011) Criminal Justice and Neoliberalism. London: Palgrave Macmillan.

Bews L (2018) MSPs vote to scrap controversial sectarianism law. The Scotsman, 15 March. Available at: https://www.scotsman.com/news-2-15012/msps-vote-to-scrap-controversialsectarianism-law-1-4706565 (accessed 10 April 2019).

Bradley J (2006) Sport and the contestation of ethnic identity: Football and Irishness in Scotland. Journal of Ethnic and Migration Studies 32(7): 1189-1208.

Braiden G (2013) Ministers face questions over Green Brigade march row. The Herald, 19 March. Available at: https://www.heraldscotland.com/news/13096688.ministers-face-questionsover-green-brigade-march-row/ (accessed 5 June 2019).

Brick C (2000) Taking offence: Modern moralities and the perception of the football fan. Soccer \& Society 1(1): 158-172.

Bruce S and Glendinning T (2017) Sectarianism in the Scottish Labour Market; what the 2011 Census Shows. Scottish Affairs 26(2): 163-175.

Bruce S, Glendinning T and Rosie M (2004) Sectarianism in Scotland. Edinburgh: Edinburgh University Press.

Cairney P (2011) The Scottish Political System since Devolution. Exeter: Imprint Academic.

Cairney P (2016) The future of Scottish government and public policy: A distinctive Scottish style? In: McTavish D (ed.) Politics in Scotland. London: Routledge, pp. 213-228.

Cairney P (2017) Evidence-based best practice is more political than it looks: A case study of the 'Scottish Approach'. Evidence \& Policy 13(3): 499-515. 
Cairney P, Russell S and St Denny E (2016) The 'Scottish approach' to policy and policymaking: What issues are territorial and what are universal? Policy \& Politics 44(3): 333-350.

Carnochan J (2017) Law and order: Politically astute and/or smart on crime? In: Hassan G and Barrow S (eds) A Nation Changed? The SNP and Scotland Ten Years on. Luath Press: Edinburgh, pp. 151-154.

Crawford J (2013) The politics of anti sectarianism. In: Flint J and Kelly J (eds) Football, Bigotry and Scotland. Edinburgh: Edinburgh University Press, pp. 180-193.

Croall H (2012) Criminal justice, social inequalities and social justice. In: Mooney G and Scott G (eds) Social Justice and Social Policy in Scotland. Bristol: Policy Press, pp. 179-201.

Devine T (2008) The end of disadvantage? The descendants of Irish-Catholic immigrants in modern Scotland since 1945. In: Mitchell M. (ed) New Perspectives on the Irish in Scotland. Edinburgh: John Donald, pp. 191-207.

Devine T (2018) Why Sectarianism in Scotland is on its death bed. The Herald, 31 March. Available at: https://www.heraldscotland.com/opinion/16130742.tom-devine-why-sectarianism-in-scotland-is-on-its-death-bed/ (accessed 30 March 2019).

Fans Against Criminalisation (n.d) Available at: http://fansagainstcriminalisation.com (accessed 25 May 2019).

Flint J and Kelly J (2013) Football and bigotry in Scotland. In: Flint J and Kelly J (eds) Football, Bigotry and Scotland. Edinburgh: Edinburgh University Press, pp. 3-18.

Garland D (2001) The Culture of Control: Crime and Social Order in Contemporary Society. Oxford: Oxford University Press.

Hamilton-Smith N and McArdle D (2013) England's act, Scotland's shame and the limits of law. In: Flint J and Kelly J (eds) Football, Bigotry and Scotland. Edinburgh: Edinburgh University Press, pp. 130-144.

Hamilton-Smith N, Anderson S, Simpson I, et al. (2015) An evaluation of Section 1 of the Offensive Behaviour at Football and Threatening Communications (Scotland) Act 2012. Available at: https://www.gov.scot/publications/evaluation-section-1-offensive-behaviourfootball-threatening-communications-scotland-act-2012/ (accessed 16 February 2019).

Harkins D (2018) Call for review into funding of anti-sectarianism initiatives. Scottish Catholic Observer, 30 March. Available at: http://www.sconews.co.uk/latest-edition/55192/call-forreview-into-funding-of-anti-sectarianism-initiatives/ (accessed 30 May 2019).

Harvey D (2007) A Brief History of Neoliberalism. London: Oxford University Press.

Howard League Scotland (2018) Critical issues in Scottish penal policy: Inequality \& imprisonment. Howard League Scotland, 18 September. Available at: http://howardleague.scot/tags/ imprisonment-rates

Hutcheon P (2015) Revealed: How Police Scotland tried to undermine criticism of stop and search. The Herald, 17 May. Available at: https://www.heraldscotland.com/news/13214134. revealed-how-police-scotland-tried-to-undermine-criticism-of-stop-and-search/ (accessed 11 May 2019).

Johnston C and Mooney G (2007) 'Problem' people, 'problem' spaces? New labour and council estates. In: Atkinson R and Helms G (eds) Securing an Urban Renaissance: Crime, Community, and British Urban Policy. Bristol: Policy Press, pp. 125-139.

Keating M, Stevenson L, Cairney P, et al. (2003) Does devolution make a difference? Legislative output and policy divergence in Scotland. The Journal of Legislative Studies 9(3): 110-139.

Kelly J (2010) ‘Sectarianism' and Scottish football: Critical reflections on dominant discourse and press commentary. International Review for the Sociology of Sport 46(4): 418-435.

Lavalette M and Mooney G (2013) The Scottish state and the criminalisation of football fans. Criminal Justice Matters 93(1): 22-24. 
Law A (2016) Sectarianism, criminalisation and the civilising process in Scotland. In: Croall H, Mooney G and Munro M (eds) Crime, Justice and Society in Scotland. London: Routledge, pp. 99-114.

Law A and Mooney G (2012) The decivilizing process and urban working-class youth in Scotland. Social Justice 38(4): 106-126.

Lijphart A (1999) Patterns of Democracy. New Caven, CT: Yale University Press.

McAra L (1999) The politics of penality: An overview of the development of penal policy in Scotland. In: Duff P and Hutton N (eds) Criminal Justice in Scotland. Aldershot: Ashgate, pp. 355-380.

McAra L (2008) Crime, criminology and criminal justice in Scotland. European Journal of Criminology 5(4): 481-504.

MacAskill K (2016) 'It is right to bring to book those who perpetrate offensive behaviour at football grounds and elsewhere'. The Herald, 16 March. Available at: https://www.heraldscotland.com/opinion/14345916.kenny-macaskill-it-is-right-to-bring-to-book-those-whoperpetrate-offensive-behaviour-at-football-grounds-and-elsewhere/ (accessed 27 May 2019).

McBride M (2011) Dealing with the sectarian 'problem' in Scotland: An analysis of press coverage of religious bigotry in Scottish football. MSc Thesis, University of Glasgow, Glasgow.

McBride M (2014) Can new legislation succeed in wiping out the sectarian problem in Scotland? Scottish Association for the Study of Offending 20: 39-50.

McBride M (2017) The Offensive Behaviour at Football and Threatening Communications (Scotland) Act 2012 - Assessing the case for repeal. Edinburgh Law Review 21(2): 234-239.

McBride M (2018) Rethinking sectarianism: A qualitative exploration of the meanings and experiences of football supporters in the west of Scotland. PhD Thesis, University of Glasgow, Glasgow.

MacLennan S (2016) Safer and stronger? The decline of managerial competence and liberal welfarism in justice. Scottish Affairs 25(1): 62-82.

McNeill F (2011) Determined to punish? Scotland's choice. In: Hassan G and Ilet R (eds) Radical Scotland: Arguments for Self-Determination. Edinburgh: Luath Press, pp. 128-142.

Malloch M and Goodall K (2013) Women, football and communities: Gendered conceptualisations of 'sectarianism'. In: Flint J and Kelly J (eds) Football, Bigotry and Scotland. Edinburgh: Edinburgh University Press, pp. 163-179.

May A (2015) An 'Anti-Sectarian' act? Examining the importance of national identity to the 'Offensive Behaviour at Football and Threatening Communications (Scotland) Act'. Sociological Research Online 20(2): 173-184.

Mooney G and Scott G (eds) (2012) Social Justice and Social Policy in Scotland. Bristol: Policy Press.

Mooney G, Croall H, Munro M, et al. (2015) Scottish criminal justice: Devolution, divergence and distinctiveness. Criminology and Criminal Justice 15(2): 205-224.

Murray K (2014) Stop and search in Scotland: An evaluation of police practice. SCCJR report 01/2014. Available at: http://www.sccjr.ac.uk/wp-content/uploads/2014/01/Stop_and_Search in_Scotland1.pdf

Murray $\overline{\mathrm{K}}$ and Harkin D (2017) Policing in cool and hot climates: Legitimacy, power and the rise and fall of mass stop and search in Scotland. The British Journal of Criminology 57(4): 885-905.

Nixon J, Pawson H and Sosenko F (2010) Rolling out anti-social behaviour families projects in England and Scotland: Analysing the rhetoric and practice of policy transfer. Social Policy \& Administration 44(3): 305-325.

Offensive Behaviour at Football and Threatening Communications (OBTC) (Scotland) Act (2012) Available at: http://www.legislation.gov.uk/asp/2012/1/contents/enacted 
Offensive Behaviour at Football and Threatening Communications (OBTC) (Scotland) Bill (2011) Policy Memorandum: Session 4. SP Bill 1-PM. Edinburgh: Scottish Parliament. Available at: http://www.parliament.scot/S4_Bills/Offensive\%20Behaviour\%20at\%20Football\%20and \%20Threatening\%20Communications\%20(Scotland)\%20Bill/b1s4-introd-pm.pdf

Prior D (2009) The 'problem' of anti-social behaviour and the policy knowledge base: Analysing the power/knowledge relationship. Critical Social Policy 29(10): 5-23.

Rosie M (2015) The sectarian iceberg? Scottish Affairs 24(3): 328-350.

Scottish Government (2015) Tackling Sectarianism and Its Consequences in Scotland: Final Report of the Advisory Group on Tackling Sectarianism in Scotland, April 2015. Available at: https://www2.gov.scot/Resource/0047/00477619.pdf (accessed 16 December 2019).

Scottish National Party (SNP) (2015) How are the SNP tackling sectarianism in Scotland. Available at: https://www.snp.org/?s=sectarianism (accessed 29 May 2019).

Scottish Parliament (2015) Official Report: Meeting of the Parliament, 16 June 2011. Available at: http://www.parliament.scot/parliamentarybusiness/report.aspx? $\mathrm{r}=6313 \& \mathrm{i}=57515 \& \mathrm{c}=0 \& \mathrm{~s}$ $=16 \% 2520$ June $\% 25202011$

Scottish Parliament Justice Committee (2011a) Official Report, 15th Meeting 2011, Session 4. Edinburgh: Scottish Parliament.

Scottish Parliament Justice Committee (2011b) Official Report, Justice Committee 22 November 2011. Edinburgh: Scottish Parliament.

Scottish Parliament Justice Committee (2011c) Report on the Offensive Behaviour at Football and Threatening Communications (Scotland) Bill at Stage 26 October 2011. Edinburgh: Scottish Parliament.

Waiton S (2018) Criminalising songs and symbols in Scottish Football: How anti-sectarianism legislation has created a new 'sectarian' divide in Scotland. Soccer and Society 19(2): 169-184.

Walker G (2001) Identity questions in contemporary Scotland: Faith, football and future prospects. Contemporary British History 15: 41-60.

\section{Author biography}

Maureen McBride is a Sociologist who works as a Research Associate on the Children's Neighbourhoods Scotland project based at the University of Glasgow. Maureen's research interests include class inequalities, racialisation and racism, sectarianism and football. 